\title{
Preservice Teachers on Their Way to Becoming Reflective Practitioners: The Relevance of Freedom of Choice in Research-Based Learning
}

\author{
Franziska Nikolov, Humboldt-Universität zu Berlin \\ Constanze Saunders, Humboldt-Universität zu Berlin \& Friedrich-Schiller-Universität Jena \\ Heike Schaumburg, Humboldt-Universität zu Berlin
}

\begin{abstract}
According to self-determination theory, the feeling of autonomy during learning is a prerequisite for intrinsically motivated learning. Applied to research-based learning in teacher education, choices in designing a research project for the school context might foster a researching-reflective attitude toward practice. This hypothesis was tested with a sample of 1,133 preservice teachers in a program at a large German university. Undergraduate students were surveyed regarding their beliefs about a reflective teaching practice at the beginning and the end of their research course, as well as the nature of freedom of choice within their project work. Multiple regression analysis showed that freedom for students in choosing the research instrument was positively associated with their beliefs about the benefits of conducting research for their teaching practice.
\end{abstract}

Keywords: reflective practice, research-based learning, self-determination, teacher education, undergraduate research

doi: $10.18833 /$ spur/3/4/6

Research-based learning (RBL) as a higher education approach aiming at acquiring content knowledge and research competencies is attracting growing attention in many German university programs. It links research and teaching within the university more closely, meeting the demand for Wilhelm von Humboldt's educational ideal of "Bildung durch Wissenschaft"-learning and education through science. In teacher education, RBL has been incorporated into many postsecondary curricula (Schüssler et al. 2017), mostly as an educational approach in courses accompanying preservice teachers' school practicums in their bachelor's and master's program. As part of their practicum, preservice teachers design and conduct a research project involving their practicum school. Although student research in research-oriented academic disciplines is not an epistemological novelty, RBL meets acceptance problems in German teacher education, as most programs' objectives are more closely linked to application outcomes for teaching (Fichten and Weyland 2018). However, as preservice teachers face changing conditions and challenges in schools, it is important to inspire them to engage in research. This article addresses this issue based on quantitative data gathered from a larger higher education research project (Saunders 2017).

\section{Research-Based Learning in Teacher Education and Beliefs about Reflective Teaching Practice}

Although many academic disciplines are research-oriented by nature, the evidence-based approach in teacher education programs is relatively new in some countries (OECD 2005a). The significant part of the German teacher education curriculum consists of content courses, subject-specific pedagogical theory, and general education courses (Terhart 2004). This status does not live up to the international demand for continuous school quality development in a fast-changing world (see, for example, European Commission 2014; OECD 2005b). Given the necessity that school organization and teaching itself should undergo constant evidence-based development (Sekretariat der Kultusministerkonferenz 2019), the next generations of teachers ought 
to be introduced to reading and conducting research so that research and science are incorporated into their selfunderstanding as professionals.

Besides acquisition of content knowledge and research competencies, RBL courses aim at affecting the development of a researching-reflective attitude (Fichten 2010; Gess, Deicke, and Wessels 2017). A researchingreflective attitude can be defined as a research-oriented, critical-reflective attitude about personal teaching practice, which helps teachers deal with varying demands in modern classrooms (Saunders, Gess, and Lehmann, forthcoming). This definition follows the ideal of the "reflective practitioner" by Dewey (1910) as well as by Schön (1991; see Farrell 2012 and Fichten 2010). According to Schön (1991), reflection on practice is necessary to create a corrective to entrenched educational beliefs and to question hidden principles in personal practice. Thus, reflection helps with explaining unexpected situations and framing problems in a new way. As the drawn ideal of the "reflective practitioner" is seen as a constant objective for teachers at school, the present study views the development of a researching-reflective attitude as an integral step on the way toward this ideal. Research has shown that this attitude is already an accepted educational objective by some teacher educators (Brew and Saunders 2020). Research-based learning assists in developing a researching-reflective attitude, as it supports systematic perception and reflection of teaching practice guided by empirical knowledge (Fichten 2010). This is based on the view that "dealing with the complexity of the teaching profession has structural similarities to research activities and requires a 'quasi-experimental' approach to teaching practice" (Fichten 2010, 141, translated by the authors). However, it is still unclear whether and how this learning approach encourages the development of a researchingreflective attitude.

Recent evaluations on research-based learning courses in teacher education at German universities found low student appreciation rates for RBL and its intended goals: the preservice teachers considered the research projects to be unnecessary and irrelevant for their future teaching routine (Fichten and Weyland 2018). However, ratings were more positive when the preservice teachers investigated their own teaching, problems that they had experienced, or questions in which they had intrinsic interest (Fichten and Weyland 2018; Gresch, Hammann, and Konnemann 2016). Furthermore, an interview study with academic experts revealed that an existing personal thematic interest is needed to begin and master challenging situations in the RBL process (Wessels et al. 2018). In accordance with these results about German RBL courses, international studies illustrated that preservice teachers need to be actively and independently participating in an academic research process to appreciate the potentials of research-based learning (Afdal and Spernes 2018; Niemi and Nievgi 2014). These findings imply that freedom within the act of researching might positively influence attitudes about student research.

\section{Freedom of Choice in Research-Based Learning}

According to the self-determination theory of Deci and Ryan (1987), a certain level of autonomy - one of the three basic needs in learning besides competence and relatedness - is a requirement for motivating individuals to take charge of their own learning. Nevertheless, a focus on autonomy is rarely found in the literature about developing research skills (McCarthy 2015). Exceptions to this are Willison and O'Regan's Research Skills Development framework (2007) and Brew's Research-Based Learning Decision-Making Wheel Model (2013).

Willison and O'Regan (2007) view autonomy as being expanded across a five-level continuum of university students' research development. Initially, all facets of inquiry (e.g. question design, data collection, and analysis) are implemented with a low level of student autonomy, using guided, prescribed tasks. After increasing levels of decision-making across the course of the research project(s), students initiate research tasks and work independently on the highest level.

In contrast, Brew (2013) sees student autonomy as integral to an RBL course from the very beginning and sets up a model for analyzing, designing, and conducting such courses. According to her Wheel Model, students can be given different levels of choice, which pertain to various aspects of a research project. The Wheel Model allows different combinations of given and chosen aspects (such as topic, research question, and analyses) within a research project to provide individual freedom while guiding and scaffolding students' research by the teacher educators.

As students tend to be more motivated when they are interested in the learning task and the outcomes for their own causes (Deci and Ryan 1985), it can be assumed that opportunities for self-chosen aspects in the RBL project lead to a higher intrinsic motivation for conducting research on teaching practice (Brew 2013). The stronger internal link to their research project might make the results and benefits for the preservice teachers' teaching practice more tangible and they thus might appreciate research and reflection higher than without an internal link (Fichten and Weyland 2018). However, there is no evidence so far on the particular relevance of aspects of freedom of choice within RBL courses for preservice teachers' attitudes about research and reflective practice.

\section{The Present Study}

In view of the demand to prepare preservice teachers to become active participants of evidence-based school and 
FIGURE 1. Inquiry Periods of the Accompanying Research Project on Research-Based Teacher Education

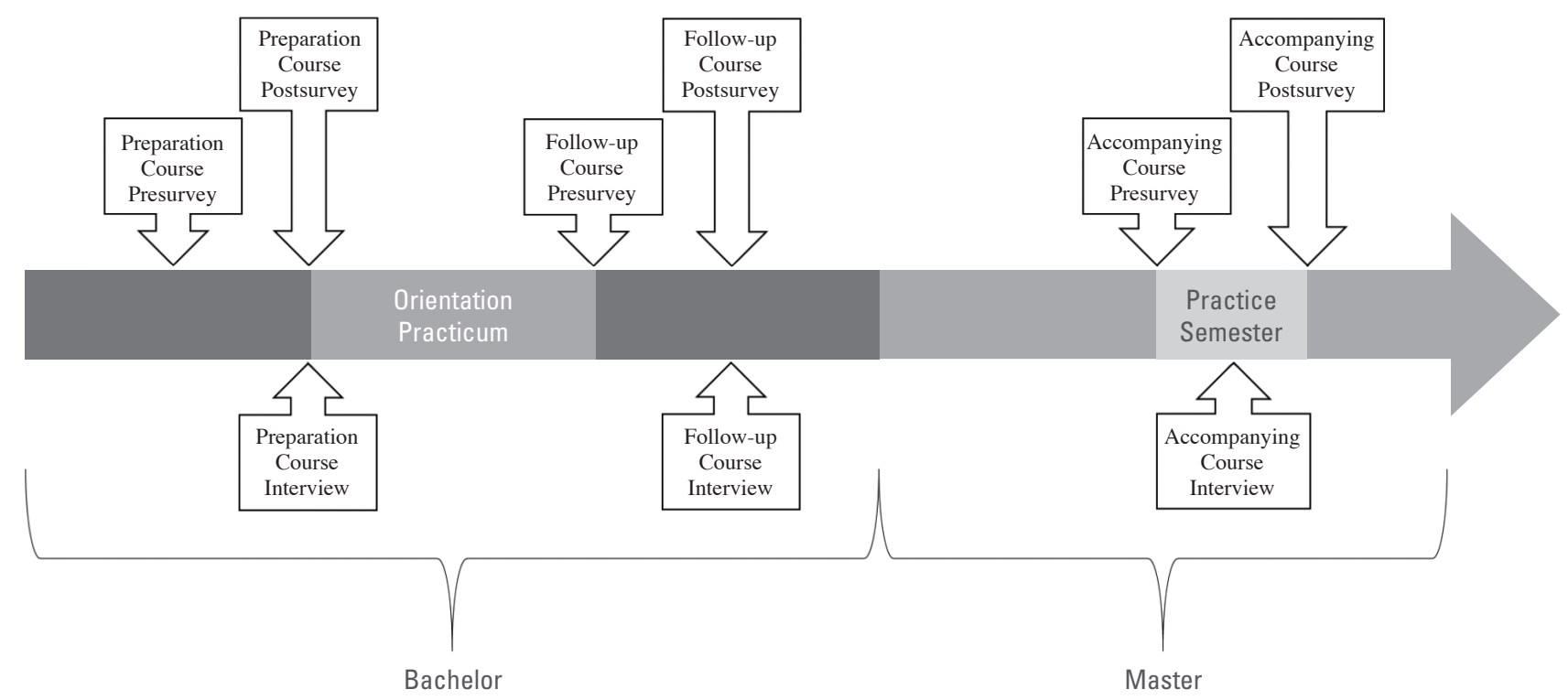

teaching development, besides acquiring research skills it is important to explore what helps them develop positive beliefs about reflective practice. Connecting the Wheel Model of Brew (2013) and the previously mentioned results about the positive effects of students' personal thematic involvement in their research studies, the question arises as to whether freedom of choice on various aspects of research projects contributes to a researching-reflective attitude in preservice teachers. More specifically, the research question of the present study is the following: which aspects of freedom of choice in research-based learning courses affect the beliefs of preservice teachers about reflective teaching practice?

According to the Wheel Model, allowing for free choices in RBL courses must be adapted to the preservice teachers' given and intended skills and attributes (Brew 2013). It is thus important to consider the different levels of academic background in this context. Hence, in this study, the focus is on undergraduate preservice teachers taking part in the mandatory RBL course before starting their school practicum.

\section{Sample}

The present study draws on data from a longitudinal multi-cohort study, which was conducted as part of a higher education research project involving qualitative and quantitative student and teacher educator surveys as well as curricular analyses. Beginning in April 2016, the study investigates the RBL practice in teacher education at a large German university (Saunders 2017). As part of the teacher education study program, mandatory research tasks are integrated in the practica at the bachelor's and master's levels, requiring all preservice teachers to conduct at least two research projects during the course of their studies (see Figure 1).

The present study focuses on the development of reflective practice during the undergraduate program. As part of the program of study, preservice teachers undertake a study module on research-based learning extending over two semesters, which consists of a preparation course, a six-week school practicum during the semester break, and a course in the subsequent semester to reflect on their practicum and their research. The preservice teachers' data collection for their research projects takes place during their practicums within the school setting, and university courses accompany this process (for example, through supporting students in designing their research projects during the preparation course and focusing on methods of data analyses in the follow-up course).

The present analysis investigates the first two measurement points of the longitudinal student survey during this study module: the beginning and the end of the RBL preparation course before the practicum in their bachelor's program, which is usually completed between the third and fourth semesters. The sample was collected over the course of seven semesters from 2016 to 2019 and consisted of 1,133 preservice teachers. On average, they had completed three semesters and were 24 years old. Female students composed 65 percent. Elementary school teacher candidates composed 29 percent, whereas the remaining 71 percent were secondary school teacher candidates. 
TABLE 1. Descriptive Statistics for TRP-Reflection Subscales

\begin{tabular}{|c|c|c|c|c|c|}
\hline Beliefs about the benefits of ... & $M_{\mathrm{T} 1}(S D)$ & $M_{\mathrm{T} 2}(S D)$ & $N_{\text {ltems }}$ & $\alpha_{\mathrm{T} 1}$ & $\alpha_{\mathrm{T} 2}$ \\
\hline students' own research & $4.23(0.52)$ & $4.26(0.50)$ & 6 & 0.71 & 0.70 \\
\hline educational science & $3.99(0.64)$ & $3.89(0.73)$ & 3 & 0.75 & 0.83 \\
\hline educational theories and empirical evidence & $3.67(0.54)$ & $3.66(0.62)$ & 5 & 0.63 & 0.75 \\
\hline $\begin{array}{l}\text { reflecting on one's own teaching practice and } \\
\text { getting feedback }\end{array}$ & $4.13(0.70)$ & $4.23(0.66)$ & 3 & 0.82 & 0.81 \\
\hline $\begin{array}{l}\text { reflecting on one's own teaching regarding the } \\
\text { complexity of the educational system }\end{array}$ & $4.04(0.75)$ & $4.13(0.74)$ & 3 & 0.81 & 0.83 \\
\hline
\end{tabular}

Note: $\alpha_{\mathrm{T} 1} / \alpha_{\mathrm{T} 2}=$ Cronbach's alpha at the beginning and the end of the RBL course. TRP = theory-research-practice

\section{Instruments}

\section{Beliefs about Reflective Practice}

Preservice teachers' researching-reflective attitude was measured using a validated scale called Beliefs about Reflective Teaching Practice $($ TRP reflection = theoryresearch-practice reflection; Saunders, Gess, and Lehmann, forthcoming), based on Kunter and colleagues (2016), Larrivee (2008), and Laschke and Felbrich (2014). It consists of five subscales regarding beliefs about the benefits of (1) students' own research, (2) educational science, (3) educational theories and empirical evidence, (4) reflecting on one's own teaching and getting feedback, and (5) reflecting on one's own teaching regarding the complexity of the educational system for their teaching practice. All 20 items required preservice teachers to use a five-point Likert scale to indicate their level of agreement $(1=$ strongly disagree to $5=$ strongly agree $)$. The internal consistency of the subscales was adequate at both measurement pointsthat is, Cronbach's alpha was greater than 0.70 for each subscale but for beliefs about educational theories and empirical evidence at the first measurement point (see Table 1). Means were relatively high on all subscales and at both measurement points, and showed a left-skewed distribution, indicating that the majority of preservice teachers scored high on TRP reflection.

\section{Freedom of Choice in the RBL Course}

To measure the freedom of choice of the preservice teachers in the RBL course, three items were assessed concerning several aspects of the RBL research project. Using a four-point Likert scale, the preservice teachers were asked to rate their freedom of choice $(1=$ completely preset to 4 = completely freely choosable) in determining (1) the research question, (2) the research method, and (3) the research instrument (see Figure 2). The mode of $M o=4$ in all three aspects indicates a high level of experienced freedom of choice in the examined RBL course groups. As the investigated RBL course took place before the practicum, in which preservice teachers collect their data, freedom of choice in other aspects of the RBL project such as statistical analyses, methods, or ways of presenting the results are asked in later measurement points of the longitudinal survey and are not included in the present analysis.

\section{Control Variables}

Control variables included the number of semesters in the program in which the surveyed preservice teachers were enrolled as well as a dummy variable indicating whether preservice teachers studied in education programs to become elementary or secondary school teachers $(1=$ elementary school, $0=$ secondary school $)$, as more advanced students in the program and students in education programs to become elementary school teachers significantly supported reflective practice more than other students. Gender and age were not included in the models because they were not significantly correlated to beliefs about reflective teaching practice.

\section{Statistical Analysis}

To investigate the relation between freedom of choice and beliefs about reflective teaching practice, differences between TRP reflection in the beginning and at the end of the RBL course were conducted during the first step by the Wilcoxon Test in SPSS 25 as the distribution of TRP reflection is left-skewed. In a second step, bivariate correlations between the freedom of choice in the three aspects of the RBL project and the five TRP-reflection subscales were conducted in Mplus 7 (Muthén and Muthén 1998-2010). Third, based on the results of the bivariate correlations, a series of hierarchical multiple regression models was conducted, estimating the association between freedom of choice in the mentioned three aspects and TRP reflection. The "type = complex" procedure was used to take into account the hierarchical structure of the data with preservice teachers embedded in courses (Raudenbush and Bryk 2002). To address missing data, the Full Information Maximum Likelihood procedure was used, which is implemented in MPlus (FIML; Muthén and Muthén 1998-2010). 
FIGURE 2. Frequencies of Freedom of Choice in the RBL Course

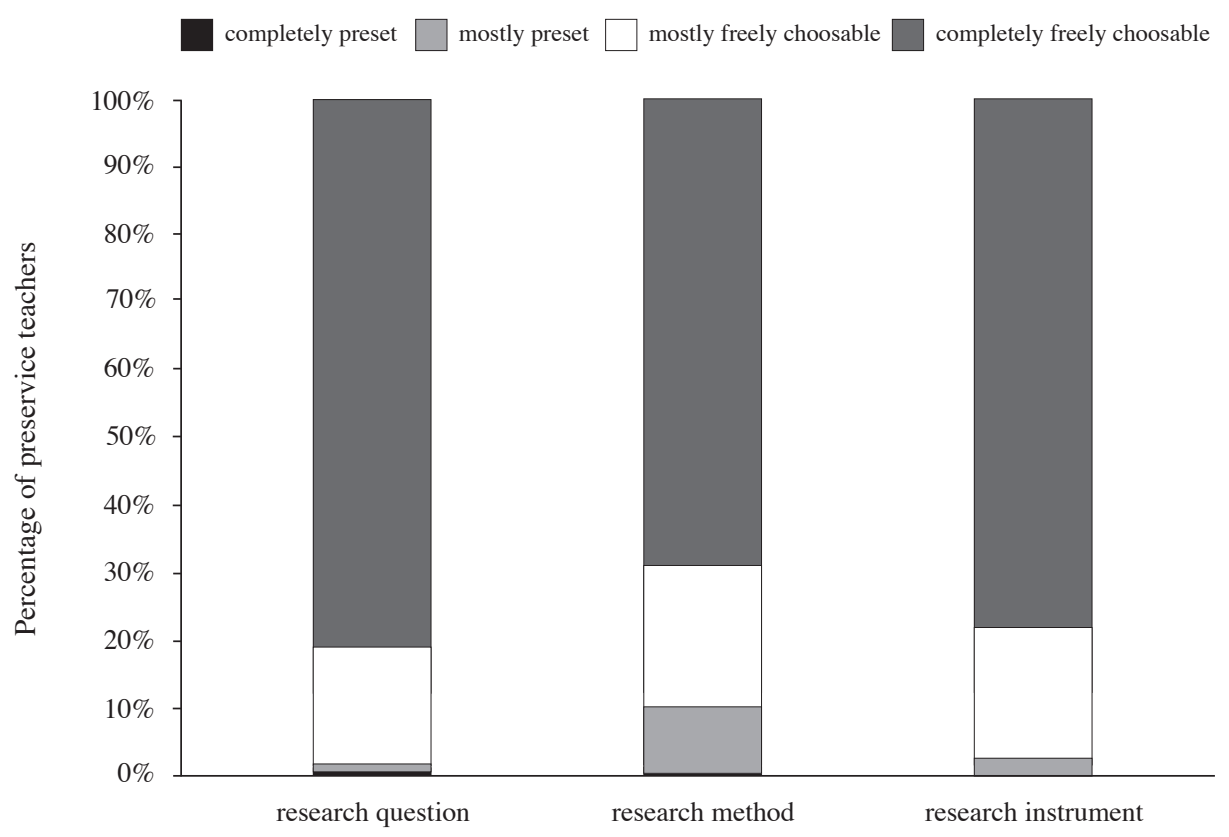

Note: $\mathrm{RBL}=$ research-based learning.

TABLE 2. Autoregression and Differences in Beliefs about Reflective Teaching Practice from the Beginning to the End of the RBL Course

\begin{tabular}{|l|c|c|c|}
\hline Beliefs about the benefits of ... & $\begin{array}{c}\text { Autoregression } \\
ß 1 / \mathrm{T} 2\end{array}$ & $D_{M \mathrm{TT}-\mathrm{T} 1}$ & $z$ \\
\hline students' own research & $0.49^{* * *}(0.04)$ & 0.03 & $-2.79^{* * *}$ \\
\hline educational science & $0.48^{* * *}(0.04)$ & -0.10 & $-3.47^{* *}$ \\
\hline educational theories and empirical evidence & $0.50^{* * *}(0.04)$ & -0.01 & -1.10 \\
\hline $\begin{array}{l}\text { reflecting on one's own teaching practice } \\
\text { and getting feedback }\end{array}$ & $0.56^{* * *}(0.04)$ & 0.10 & $-2.69^{* *}$ \\
\hline $\begin{array}{l}\text { reflecting on one's own teaching regarding } \\
\text { the complexity of the educational system }\end{array}$ & $0.58^{* * *}(0.04)$ & 0.09 & -1.33 \\
\hline
\end{tabular}

Note: $D_{M \mathrm{~T} 2 \mathrm{-T} 1}=$ Difference in means of theory-research-practice (TRP) reflection between the beginning and the end of the research-based learning (RBL) course. $z=z$-value of the difference between T1 and T2. Standardized coefficients are reported. ${ }^{* * *} p<0.001,{ }^{* *} p<0.01,{ }^{*} p<0.05$.

\section{Results}

\section{The Development of Beliefs about Reflective} Teaching Practice

In the beginning of the RBL course, the preservice teachers scored high on beliefs about all five aspects, with means between $3.67(S D=0.54)$ for the benefits of educational theories and empirical evidence, and $4.23(S D=0.52)$ for the benefits of students' own research (see Table 1). By the end of the RBL course, the beliefs about reflective teaching practice further increased slightly; only the beliefs about benefits of educational science and about educa- tional theories and empirical evidence decreased slightly. The differences in TRP reflection between the beginning and the end of the RBL course were significant for the subscales regarding students' own research, educational science, and reflecting on one's own teaching practice and getting feedback (see Table 2).

\section{Relations between Freedom of Choice in RBL Courses and Beliefs about Reflective Teaching Practice}

Estimating bivariate correlations between freedom of choice and the five subscales of TRP reflection at measurement point $\mathrm{T} 2$ revealed that only the TRP-reflection 
TABLE 3. Bivariate Correlations between Freedom of Choice and TRP Reflection at the End of the RBL Course

\begin{tabular}{|l|c|c|c|}
\hline \multirow{2}{*}{ Beliefs about the benefits of ... } & \multicolumn{3}{|c|}{ Freedom of choice concerning the ... } \\
\cline { 2 - 4 } & $\begin{array}{c}\text { research } \\
\text { question }\end{array}$ & $\begin{array}{c}\text { research } \\
\text { method }\end{array}$ & $\begin{array}{c}\text { research } \\
\text { instrument }\end{array}$ \\
\hline students' own research & $0.10^{* *}$ & $0.07^{*}$ & $0.15^{* * *}$ \\
\hline educational science & 0.03 & 0.06 & 0.02 \\
\hline educational theories and empirical evidence & 0.04 & 0.00 & 0.00 \\
\hline $\begin{array}{l}\text { reflecting on one's own teaching practice } \\
\text { and getting feedback }\end{array}$ & 0.04 & 0.00 & 0.02 \\
\hline $\begin{array}{l}\text { reflecting on one's own teaching regarding } \\
\text { the complexity of the educational system }\end{array}$ & 0.03 & -0.05 & 0.02 \\
\hline
\end{tabular}

Note: Standardized coefficients are reported. ${ }^{* * *} p<0.001,{ }^{* *} p<0.01,{ }^{*} p<0.05$. TRP $=$ theory-research-practice. $\mathrm{RBL}=$ research-based learning.

subscale regarding the benefits of students' own research was significantly correlated to freedom of choice (see Table 3): preservice teachers rated the benefits of their own research for their teaching practice more positively when they had more freedom in choosing the research question $(\beta=0.10, p<0.01)$, the research method $(\beta=$ $0.07, p<0.05)$, or the research instrument $(B=0.15, p<$ 0.001). Accordingly, the preservice teachers gave lower ratings about the benefits of their own research for their teaching practice when they were less free in choosing the research question, the research method, or the research instrument.

\section{Associations between the Freedom of Choice and Preservice Teachers' Beliefs about the Benefits of Their Own Research over the Course of the RBL Course}

As beliefs about the benefits of preservice teachers' own research was the only TRP-reflection subscale that was significantly correlated to freedom of choice in the three aspects, this subscale became the focus of multiple regression modeling in the third step. The first model only specifies the autoregression of beliefs about benefits of preservice teachers' own research between measurement point $\mathrm{T} 1$ and $\mathrm{T} 2$, and the regression of the two control variables on benefits of preservice teachers' own research at T2. The model illustrates that the level of these beliefs at the end of the RBL course is mostly explained by the previous level of these beliefs at the beginning of the RBL course ( $(=0.47, p<0.001$; Model 1; see Table 4). In Model 2 to Model 4 , the three items pertaining to freedom of choice were added separately as independent variables, whereas in Model 5 all three aspects were specified simultaneously (see Table 4). The single Models 2 to 4 reveal a positive regression of receiving freedom in choosing the research question ( $(=0.08, p<0.05$; Model 2$)$, the research method $(\beta=0.07, p<0.05$; Model 3$)$, and the research instrument $(\beta=0.14, p<0.001$; Model 4$)$ on beliefs about the benefits of preservice teachers' own research at the end of the RBL course.

When all three aspects of freedom of choice were specified (see Model 5), only choosing the research instrument was positively associated to the focused-on subscale $(\beta=0.13$, $p<0.01)$. Thus, controlling for freedom of choice in the other two aspects, the preservice teachers who received more freedom in choosing the research instrument had more positive beliefs about the benefits of their own research for their teaching practice at the end of the RBL course than preservice teachers who received less freedom in choosing the research instrument.

\section{Discussion}

The aim of the present study was to investigate which aspects of freedom of choice in research-based learning courses affect preservice teachers' beliefs about a reflective teaching practice. The analyses revealed that preservice teachers had more positive beliefs about the benefits of their own research for their teaching practice when they were allowed to choose the research instrument in an RBL course project. Choosing the research question and choosing the research method was positively related to beliefs about the role of their own research for their teaching practice as well, but choosing the research instrument played the major role.

These results support previous research, which revealed that RBL projects need to be linked to topics that are of intrinsic interest and need to facilitate active and independent student participation to make research-based learning successful (Gresch et al. 2016; Wessels et al. 2018). If the preservice teachers could have chosen several aspects of the RBL project, it might have helped them to make sense of the research 
TABLE 4. Multivariate Regression Models Predicting Development of Beliefs about the Benefits of Students' Own Research for Their Teaching Practice from the Beginning to the End of the RBL Course

\begin{tabular}{|c|c|c|c|c|c|}
\hline \multirow[b]{2}{*}{ Variables } & \multicolumn{5}{|c|}{ Beliefs about the benefits of students' own research T2 } \\
\hline & $\begin{array}{l}\text { Model } 1 \\
ß(S E)\end{array}$ & $\begin{array}{l}\text { Model } 2 \\
ß(S E)\end{array}$ & $\begin{array}{l}\text { Model } 3 \\
ß(S E)\end{array}$ & $\begin{array}{l}\text { Model } 4 \\
ß(S E)\end{array}$ & $\begin{array}{l}\text { Model } 5 \\
ß(S E)\end{array}$ \\
\hline $\begin{array}{l}\text { Beliefs about the benefits of } \\
\text { students' own research T1 }\end{array}$ & $\begin{array}{l}0.47^{* * *} \\
(.04)\end{array}$ & $\begin{array}{l}0.46^{* * *} \\
(0.04)\end{array}$ & $\begin{array}{l}0.47^{* * *} \\
(0.04)\end{array}$ & $\begin{array}{l}0.47^{* * *} \\
(0.04)\end{array}$ & $\begin{array}{l}0.46^{* * *} \\
(0.04)\end{array}$ \\
\hline Elementary vs. secondary school & $\begin{array}{c}0.05 \\
(0.04)\end{array}$ & $\begin{array}{c}0.05 \\
(0.04)\end{array}$ & $\begin{array}{c}0.04 \\
(0.04)\end{array}$ & $\begin{array}{c}0.05 \\
(0.04)\end{array}$ & $\begin{array}{c}0.05 \\
(0.04)\end{array}$ \\
\hline Number of semesters & $\begin{array}{l}-0.07 \\
(0.04)\end{array}$ & $\begin{array}{l}-0.07 \\
(0.04)\end{array}$ & $\begin{array}{l}-0.07 \\
(0.04)\end{array}$ & $\begin{array}{l}-0.07 \\
(0.04)\end{array}$ & $\begin{array}{l}-0.07 \\
(0.04)\end{array}$ \\
\hline \multicolumn{6}{|c|}{ Freedom of choice concerning the... } \\
\hline research question & & $\begin{array}{r}0.08^{*} \\
(0.03) \\
\end{array}$ & & & $\begin{array}{c}0.04 \\
(0.03) \\
\end{array}$ \\
\hline research method & & & $\begin{array}{r}0.07^{*} \\
(0.03)\end{array}$ & & $\begin{array}{c}0.00 \\
(0.04)\end{array}$ \\
\hline research instrument & & & & $\begin{array}{l}0.14^{* * *} \\
(0.04)\end{array}$ & $\begin{array}{l}0.13^{* *} \\
(0.04)\end{array}$ \\
\hline $\mathrm{R}^{2}$ & $\begin{array}{c}0.25 \\
(0.04)\end{array}$ & $\begin{array}{c}0.25 \\
(0.04)\end{array}$ & $\begin{array}{l}0.25 \\
(0.04)\end{array}$ & $\begin{array}{c}0.27 \\
(0.04)\end{array}$ & $\begin{array}{l}0.27 \\
(0.04)\end{array}$ \\
\hline
\end{tabular}

Note: Standardized coefficients are reported. ${ }^{* * *} p<0.001,{ }^{* *} p<0.01,{ }^{*} p<0.05$. RBL $=$ research-based learning.

project for their investigated issue and to see the benefits of research for their teaching practice in general. Dealing with a topic of their practical training via a research project and developing a method and an instrument that they will apply in their forthcoming practical training require concrete ideas of systematically investigating and reflecting the practice. This experience may illustrate a direct connection between research activity and teaching practice, which initially was not clearly visible to the preservice teachers. The results are also consistent with the Research-Based Learning Decision-Making Wheel Model of Brew (2013) that advocates freedom of choice already in the beginning of a research project: the present analysis comprises undergraduate preservice teachers early in their education who were enrolled in an RBL course before their practical training; consequently, they were both new to educational research and to the practicum part of their studies.

An unexpected finding is the major role of choosing the research instrument in comparison to choosing the research question and the research method. Choosing and/ or designing the instrument may require thinking through the research topic more thoroughly than formulating a research question and choosing the method, thus leading to more intense cognitive and affective processes.

\section{Limitations and Future Research}

Despite its strength, some limitations of this study should be mentioned for a better interpretation of the results. First, as the survey did not address whether the preservice teachers were allowed to choose between given instruments such as validated scales or if they were free to create their own instruments such as formulating their own survey questions, it is not known if preservice teachers need freedom in choosing the instrument to enrich their TRP reflection. If they need freedom to formulate survey items by themselves, their research projects might fail statistical quality standards due to their novice status in educational research. Thus, their research results might not be useful for preservice teachers to draw conclusions for their practice. On the other hand, such aberrations might perhaps be an integral part of effective research-based learning, given the teacher educators' support in reflecting the instruments and results.

Second, a surprising result is that giving freedom in the three aspects of the RBL project was not associated to the other four subscales of beliefs about reflective teaching practice but only on beliefs about the role of their own research for their teaching practice. Alternative methodological approaches such as interviews with preservice teachers might offer a better understanding of the underlying mechanisms. It may be too demanding for the preservice teachers in this initial stage of the bachelor's program to extrapolate from their own research on the benefits of educational studies and theories, empirical research results, and the value of reflection for their teaching practice. To reach that point, the preservice teachers might need to finish their projects first and be provided 
with further, close support such as discussions led by their teacher educators.

Third, since the present results are limited to a sample of preservice teachers in a pre-practicum course, further analysis in the accompanying higher education research project will expose whether freedom of choice in the RBL course has effects long after the post-practicum course. By collecting data through their self-chosen instrument during their own practical training, the preservice teachers obtain direct experience and training in how to systematically reflect their teaching practice.

\section{Conclusion}

First, it can be seen as a positive result that undergraduate preservice teachers in general reported positive beliefs about a reflective teaching practice both at the beginning and the end of the investigated RBL course. Second, the results indicate that freedom of choice increases preservice teachers' value of conducting research and reflecting their teaching practice. Thus, the present study illustrates that investigating preservice teachers' experiences of researchbased learning might give helpful information for improving the effectiveness of teacher education programs.

As in the case of teacher education, most professions with practical training have to prepare students for specific occupations, whereas the demands of future professionals are uncertain due to the fast-changing future. Incorporating freedom of choice in research activities might inspire students doing their own research and encourage many future professionals to engage in a critical-reflective practice.

\section{References}

Afdal, Hilde Wågsås, and Kari Spernes. 2018. "Designing and Redesigning Research-Based Teacher Education." Teaching and Teacher Education 74: 215-228. doi: 10.1016/j.tate.2018.05.011

Brew, Angela. 2013. "Understanding the Scope of Undergraduate Research: A Framework for Curricular and Pedagogical Decision-Making." Higher Education 66: 603-618. doi: 10.1007/ s10734-013-9624-X

Brew, Angela, and Constanze Saunders. 2020. "Making Sense of Research-Based Learning in Teacher Education." Teaching and Teacher Education. An International Journal of Research and Studies 87: 1-11.

Deci, Edward L., and Richard M. Ryan. 1985. Intrinsic Motivation and Self Determination in Human Behavior. New York: Plenum Press.

Deci, Edward L., and Richard M. Ryan. 1987. "The Support of Autonomy and the Control of Behavior." Journal of Personality and Social Psychology 53: 1024-1037. doi: 10.1037/00223514.53.6.1024

Dewey, John. 1910. How We Think. London: D. C. Heath.

European Commission. 2014. Horizon Report Europe. Luxembourg: Publications Office of the European Union. Austin,
TX: The New Media Consortium. Accessed February 1, 2020. https://ec.europa.eu/jrc/en/publication/eur-scientific-and-technical-research-reports/horizon-report-europe-2014-schools-edition

Farrell, Thomas S. C. 2012. "Reflecting on Reflective Practice: (Re)Visiting Dewey and Schön." TESOL Journal 3(1): 7-16. doi: 10.1002/tesj.10

Fichten, Wolfgang. 2010. "Forschendes Lernen in der Lehrerbildung." In Neue Impulse in der Hochschuldidaktik: Sprach- und Literaturwissenschaften, edited by Ulrike Eberhardt, 127-82. Wiesbaden: Verlag für Sozialwissenschaften.

Fichten, Wolfgang, and Ulrike Weyland. 2018. "Empirie zu Forschendem Lernen: Analysen und Perspektiven unter Berücksichtigung der Evaluation von Praxissemestern." In Forschendes Lernen-The Wider View, edited by Nils Neuber, Walther Dietrich Paravicini, and Martin Stein, 47-58. Münster: WTM-Verlag.

Gess, Christopher, Wolfgang Deicke, and Insa Wessels. 2017. "Kompetenzentwicklung durch Forschendes Lernen." In Forschendes Lernen. Wie die Lehre in Universität und Fachhochschule erneuert werden kann, edited by Harald A. Mieg and Judith Lehmann, 79-90. Frankfurt am Main: Campus Verlag.

Gresch, Helge, Marcus Hammann, and Christiane Konnemann. 2016. "Forschendes Lernen im Praxissemester Biologie. Erste Erfahrungen an der Universität Münster." Journal für LehrerInnenbildung 16(4): 48-56.

Kunter, Mareike, Jürgen Baumert, Detlev Leutner, Ewald Terhart, Tina Seidel, Theresa Dicke, Doris Holzberger, et al. 2016. Dokumentation der Erhebungsinstrumente der Projektphasen des BilWiss-Forschungsprogramms von 2009 bis 2016: Bildungswissenschaftliches Wissen und der Erwerb professioneller Kompetenz in der Lehramtsausbildung (BilWiss). Die Bedeutung des bildungswissenschaftlichen Hochschulwissens. Frankfurt am Main: Goethe Universität.

Larrivee, Barbara. 2008. "Development of a Tool to Assess Teachers' Level of Reflective Practice." Reflective Practice 9(3): 341-360. doi: 10.1080/14623940802207451

Laschke, Christin, and Anja Felbrich. 2014. "Erfassung der Überzeugungen." In Teacher Education and Development Study: Learning to Teach Mathematics (TEDS-M 2008), edited by Christin Laschke and Sigrid Blömeke, 109-130. New York: Waxmann.

McCarthy, Grace. 2015. "Motivating and Enabling Adult Learners to Develop Research Skills." Australian Journal of Adult Learning 55(2): 309-330.

Muthén, Bengt O., and Linda Muthén. 1998-2010. Mplus User's Guide. 6th ed. Los Angeles: Muthén and Muthén.

Niemi, Hannele, and Anne Nievgi. 2014. "Research Studies and Active Learning Promoting Professional Competences in Finnish Teacher Education." Teaching and Teacher Education 43: 131-142. doi: 10.1016/j.tate.2014.07.006

Organisation for Economic Co-operation and Development (OECD). 2005a. Teachers Matter: Attracting, Developing and Retaining Effective Teachers. Paris: OECD. Accessed February 1, 2020. https://www.oecd.org/education/school/34990905.pdf

Organisation for Economic Co-operation and Development (OECD). 2005b. School Factors Related to Quality and Equity: 
Results from PISA 2000. Paris: OECD. Accessed February 1, 2020. http://www.oecd.org/education/school/programmeforinternationalstudentassessmentpisa/34668095.pdf

Raudenbush, Steven W., and Anthony S. Bryk. 2002. Hierarchical Linear Models: Applications and Data Analysis Methods. 2nd ed. Advanced Quantitative Techniques in the Social Sciences Series 1. London: SAGE.

Saunders, Constanze. 2017. Research-Based Learning in Teacher Education at Humboldt-Universität zu Berlin. Working Papers der AG Forschendes Lernen der DGHD Nr. 1. Berlin: HumboldtUniversität zu Berlin. Accessed February 1, 2020. https://uol.de/ fileadmin/user_upload/flif/Homepage_neu/Working_Paper/1409_Online_Saunders_FL_im_LA_HU_Berlin_081117.pdf

Saunders, Constanze, Christopher Gess, and Malte Lehmann. Forthcoming. "Forschendes Lernen im Lehramt: Entwicklung eines Instruments zur Erfassung von Überzeugungen zur forschend-reflexiven Lehrpraxis." In Forschendes Lernen-Theoretische Grundlagen und Empirische Befunde, edited by Carmen Wulf, Susanne Haberstroh, and Margrit Petersen. Wiesbaden: Verlag für Sozialwissenschaften.

Schön, Donald A. 1991. The Reflective Practitioner: How Professionals Think in Action. Aldershot, UK: Ashgate.

Schüssler, Renate, Anke Schöning, Volker Schwier, Saskia Schicht, Johanna M. Gold, and Ulrike Weyland. 2017. Forschendes Lernen im Praxissemester: Zugänge, Konzepte, Erfahrungen. Bad Heilbrunn: Verlag Julius Klinkhardt.

Sekretariat der Kultusministerkonferenz. 2019. Standards für die Lehrerbildung: Bildungswissenschaften-Beschluss der Kultusministerkonferenz vom 16.12.2004, I. D. F. Vom 16-05-2019. Berlin: Sekretariat der Ständigen Konferenz der Kultusminister der Länder in der Bundesrepublik Deutschland. Accessed February 1, 2020. https://www.kmk.org/fileadmin/veroeffentlichungen_beschluesse/2004/2004_12_16-Standards-LehrerbildungBildungswissenschaften.pdf

Terhart, Ewald. 2004. "Struktur und Organisation der Lehrerbildung in Deutschland." In Handbuch Lehrerbildung, edited by Sigrid Blömeke, Peter Reinhold, Gerhard Tulodziecki, and Johannes Wildt, 37-59. Bad Heilbrunn/Braunschweig: Klinkhardt and Westermann.

Wessels, Insa, Julia Rueß, Lars Jenßen, Christopher Gess, and Wolfgang Deicke. 2018. "Beyond Cognition: Experts' Views on Affective-Motivational Research Dispositions in the Social Sciences." Frontiers in Psychology 9: 1300. doi: 10.3389/ fpsyg.2018.01300
Willison, John, and Kerry O'Regan. 2007. "Commonly Known, Commonly Not Known, Totally Unknown: A Framework for Students Becoming Researchers." Higher Education Research and Development 26: 393-409. doi: 10.1080/07294360701658609

\section{Franziska Nikolov}

Humboldt-Universität zu Berlin, franziska.nikolov@hu-berlin.de

Franziska Nikolov obtained a PhD from the Freie Universität Berlin while working in a predoctoral position at Leibniz Institute for Research and Information in Education (DIPF). She studied educational science at Freie Universität Berlin and Humboldt-Universität zu Berlin (HUB). She currently is a postdoctoral researcher at the Professional School of Education at HUB, focusing on how research-based learning in teacher education can foster a researching-reflective attitude. Her main areas of interest are students' psycho-social development at school, effects due to class composition, and adaptive teaching.

Constanze Saunders teaches and researches at HUB as well as serves as chair of Methodology and Didactics in German as a foreign and second language at FriedrichSchiller-Universität Jena. She earned a master's degree in German studies from the University of Arizona, as well as a master's degree in German as a foreign language and American studies and a PhD from the University of Leipzig. She is interested in the role of research and research-based learning in teacher education.

Heike Schaumburg is a scientific staff member at the Institute of Education at $H U B$ and previously served as vice-director of HUB's Professional School of Education. She obtained a PhD in educational science and psychology from Freie Universität Berlin and holds master's degrees in psychology from Freie Universität Berlin and in instructional technology from Indiana University. Her research focuses on the use of digital media in the classroom and its effects on learning, instruction, and school development. She is interested in ways to successfully integrate theory and practice into preservice teacher education. 